\title{
RENOVATION AND ADAPTATION OF THE HISTORIC OLSZTYN PURIFICATION HOUSE BET TAHARA INTO A PUBLIC UTILITY BUILDING
}

\author{
Barbara Maria DEJA ${ }^{1}$ \\ University of Warmia and Mazury in Olsztyn, \\ Faculty of Geodesy, Geospatial and Civil Engineering, Olsztyn, Poland
}

\section{Abstract}

The historic Jewish Purification House Bet Tahara was erected in Olsztyn in 1913 on the basis of the debut design of Erich Mendelsohn, a world-famous architect born in Olsztyn. The most valuable element of the building is a self-supporting pyramid vault above a mourning hall. The paper presents the interesting structure of the building, its technical condition before renovation, as well as the scope of work involved in adapting it into a public utility building - MENDELSOHN HOUSE Intercultural Dialogue Centre. The undertaking was executed thanks to the commitment of the building's leaseholder "Borussia" Cultural Community Association, which raised money for this goal from public funds.

Keywords: historic building renovation, adaptation, Jewish Purification House, public utility building

\section{INTRODUCTION}

One of the historic buildings in Olsztyn which has recently been subjected to renovation and adaptation to a new service function is the former Jewish Purification House - Bet Tahara, built in 1913 based on a design by the world famous architect - Erich Medelsohn [4].

\footnotetext{
${ }^{1}$ Corresponding author: University of Warmia and Mazury in Olsztyn, Faculty of Geodesy, Geospatial and Civil Engineering, Heweliusza st 4, 10-724 Olsztyn, Poland; e-mail: barbara.deja@uwm.edu.pl, tel. +48895233818
} 
Erich Medelsohn was born in Olsztyn (at the time Allenstein) in 1887. After graduating from secondary school in his home town, Erich assumed architectural studies in Berlin, though ultimately receiving his degree at the Technical University in Munich. The project design of the Purification House in Olsztyn was a student work of his [4].

Mendelsohn worked in Munich, Berlin, England, Israel and the USA, where he died in 1953. His novel and versatile works left behind a legacy in the form of numerous publications which were theoretical and critical in nature, as well as completed buildings, among which we can list: Einstein's tower in Potsdam, the department store Petersdorf ("Kameleon") in Wrocław, or the WOGA complex in Berlin.

The article presents an analysis of the value and technical condition of, as well as works connected with renovating and adapting the Purification House into the Center for Intercultural Dialogue and Museum of Erich Mendelsohn.

\section{LOCATION AND HISTORICAL BACKGROUND OF BET TAHARA}

The former Jewish Purification House (preburial house) is located on Zyndram of Maszkowiece Street, on a land property which also covers the area of a nineteenth century Jewish cemetery in the central part of Olsztyn. The real estate is listed in the register of historic monuments of the WarmińskoMazurskie Voivodeship [1]: Jewish cemetery within the city park, under the number A-2393 (entry dated 20.04.1988); Purification House under the number A-2370 (entry dated 27.02.1988). In the direct proximity of the preburial house is the so-called gardener's house. Originally, the cemetery gate was located between the two buildings.

The building complex served its function until the Second World War. After the war, the formal owner of the unused building was the Reich Association of Jews. Following nationalization (in 1951), the building was handed over to the Olsztyn State Archives, which adapted it to their needs. The buildings ceased to be used in 1966, when the Archives were moved to a different location, leading to their progressive destruction.

In the year 2000, the real estate along with the area of the former cemetery (removed in the 60's of the past century) was taken over by the Union of Jewish Religious Communities in the Republic of Poland - Foundation for the Preservation of Jewish Heritage, which rents it out to the "Borussia" Cultural Community Association.

In the years 2006-2013, conservation and renovation works were carried out on the building complex, overseen by offices charged with the conservation of 
historic monuments, and in cooperation with "Borussia", the Rabbinical Council, and the Foundation for the Preservation of Jewish Heritage [2]. In March 2013, the renovated building was completed and once again made available for use.

\section{DESCRIPTION OF ORIGINAL BUILDING}

The building of the Jewish Purification House in Olsztyn differs in style from other existing buildings of this type (compare, e.g. the Beth Tahara in Gliwice). It is a modernist building, characterized by simplicity and minimalism (Fig. 1), which is unusual considering Erich Mendelsohn designed it in 1912, when modernism was not yet popular.

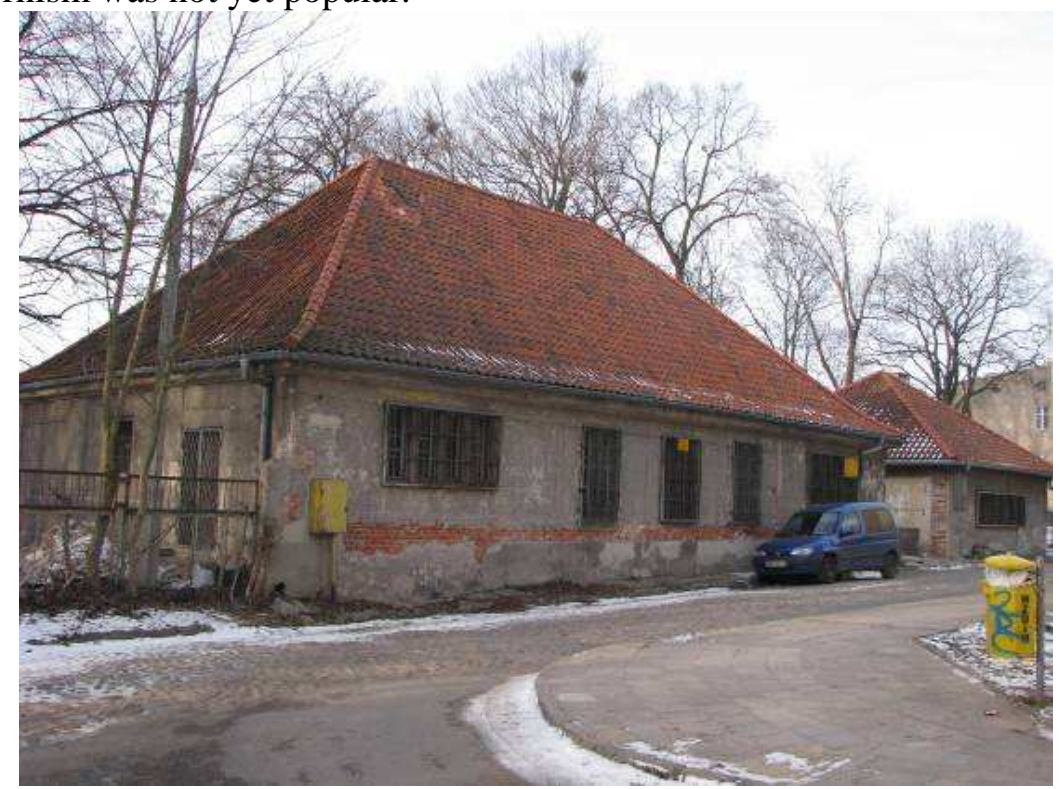

Fig. 1. View of the front elevation of the Bet Tahara prior to renovation [photograph by B.M. Deja, 2011]

The floor plan of the Bet Tahara results from the requirements of the rituals of Jewish burial. The walk-through layout of the rooms (Fig. 2) reflected man's journey after death. Just left of the entrance, next to the atrium (No. 1 in Fig. 3), was the ritual washing room (No. 2), in which the body of the dead was cleansed, followed by the mourning hall (No.3), where prayers were said for the deceased, and a mortuary (No. 4) through which the corpse was carried into the cemetery. There was also an additional prayer room in the building for the kohen (Jewish priest). 


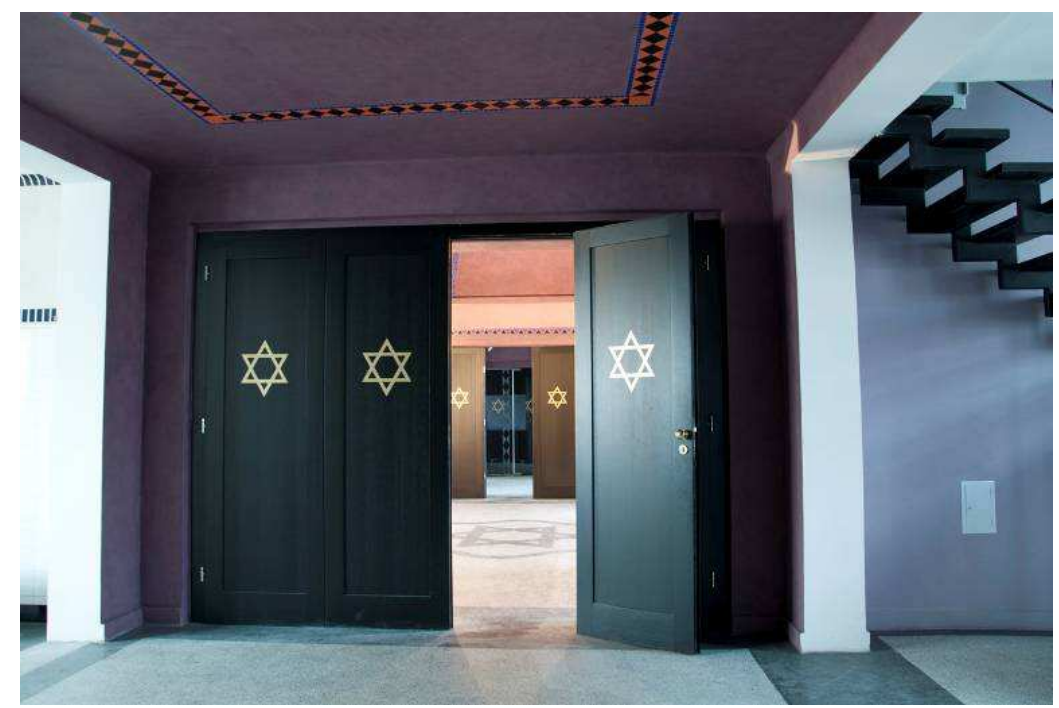

Fig. 2. Walk-through layout of rooms in the Purification House, in the foreground - the atrium, on the left - the ritual washing room [photograph by A. Skrzypińska, 2014]

The Olsztyn preburial house is a masonry, one-storey building (Fig. 4), constructed on a rectangular floor layout measuring $18.66 \mathrm{~m}$ by $11.88 \mathrm{~m}$ (Fig. 3). The building has a partial basement and a formerly unused attic, the entrance to which is located on the north-eastern side of a transverse wall.

The building is situated on a shallow brick foundation in lime mortar. The basement, which is covered by a brick-infill ceiling of the "Klein" type, could not be accessed from the ground floor in the past (Fig. 4). Its entrance was possible through a door in the south-western elevation. The floors in the building were designed as wooden beam structures with sound boarding [2].

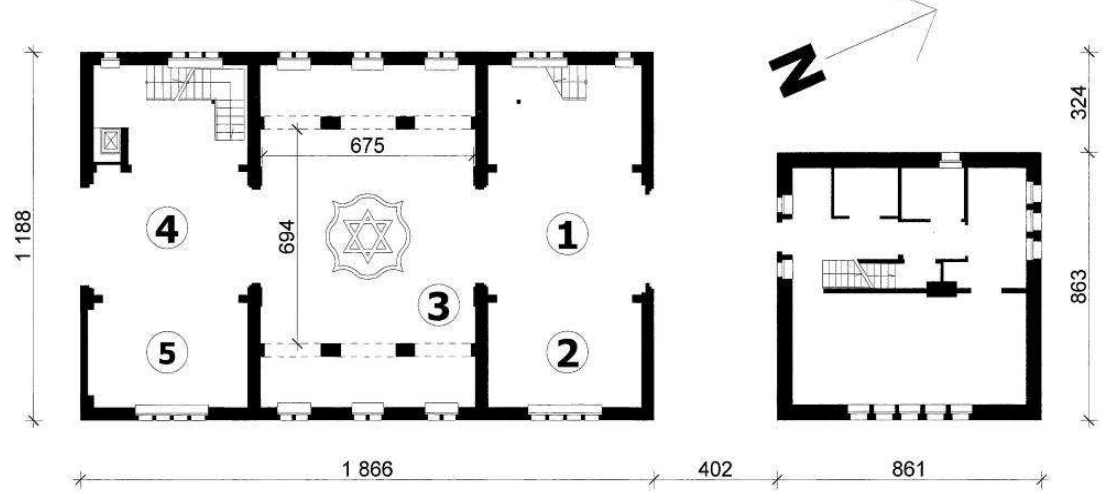

Fig. 3. Layout of the ground floor of the preburial house [drawing by M. Zyskowska] 


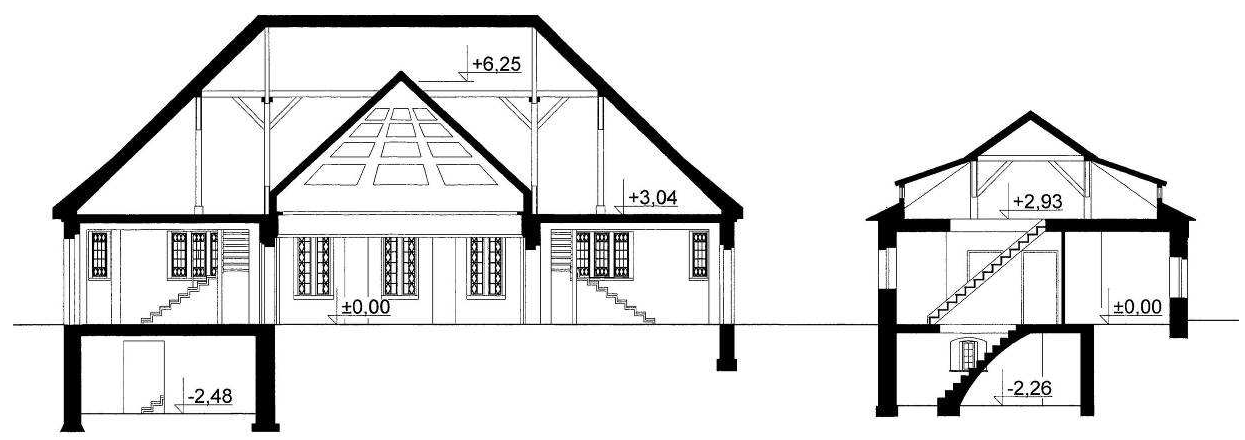

Fig. 4. Longitudinal section of the Bet Tahara [Drawing by M. Zyskowska]

The load-bearing structure of the high hip roof (covered with clay pantiles) is a truss system made of purlin and tenaille structure, additionally reinforced with a king post. Small dormers aiding ventilation of the attic were placed on the north-western and south-eastern slopes of the roof.

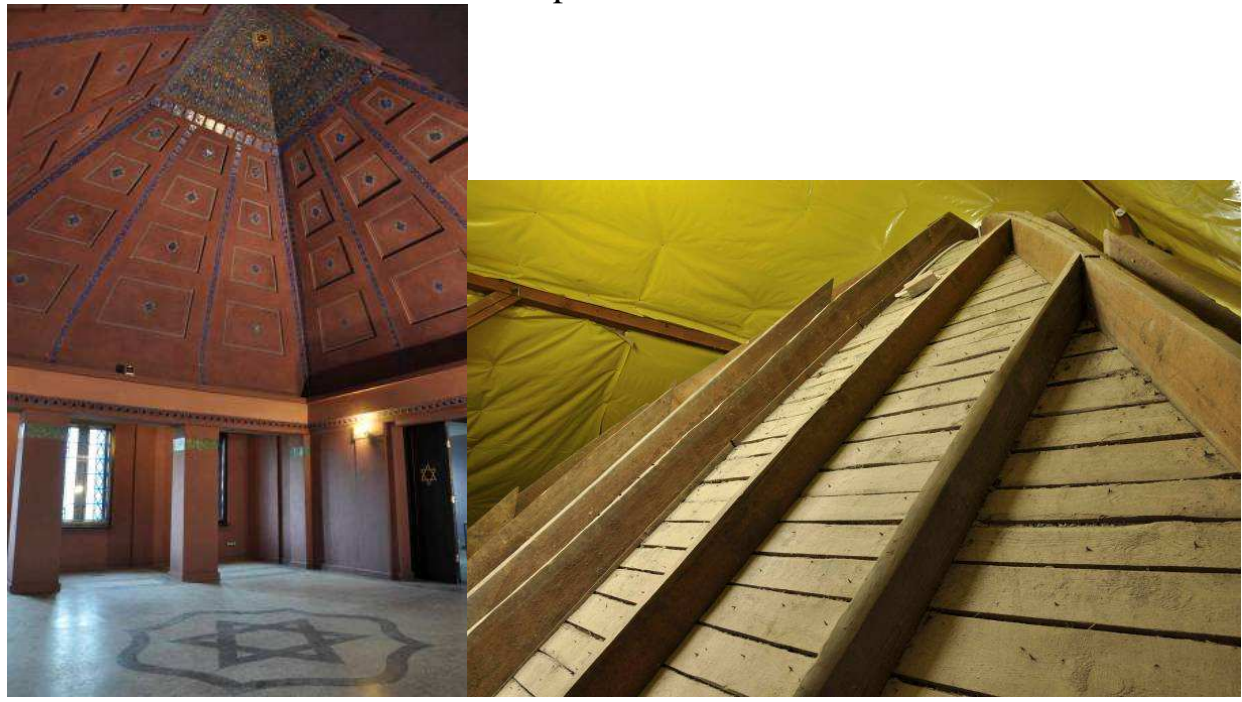

Fig. 5, 6. Mourning hall with a pyramid vault (following renovation) and wooden structure of the self-bearing vault [photograph by A. Skrzypińska, 2014]

On the ground floor of the building, there are two horizontal load bearing walls, which define the rectangular interior of the mourning hall (No. 3 in Fig. 3). The most valuable element of the mourning hall is the $3.21 \mathrm{~m}$ high, self-bearing vault, which is shaped like a frustum of a pyramid constructed on the layout of a square, measuring $6.74 \mathrm{~m}$ by $6.94 \mathrm{~m}$ (Fig. 3 , 4). Its load-bearing construction is 
made up of rafters held up by the transverse walls and steel binding joists supported by two pairs of brick columns (Fig. 5, 6).

The rafters were covered with wooden boards from the inside, onto which plaster was applied on reed mats, stiffeners and coffers tapering towards the peak were formed, and the entire surface decorated with polychromy and ceramic mosaics. Golden inscriptions in Hebrew were placed on the crowning cornice [2]. Proper proportions and decorations of the pyramidal vault make the height of the pyramid appear much greater than it actually is.

The reason why E. Mendelsohn introduced a separate vault in the mourning hall were the requirements of ritual cleanliness of the kohen, who could not share the same roof as the deceased during the funeral [3].

\section{STATE OF THE BUILDING PRIOR TO RENOVATION}

Numerous changes were introduced to the Bet Tahara building complex in the second half of the XX century. In the 50's of the past century, on the southeastern side of the ground floor of the building, a boiler room was added, which required lowering the level of the floor and the construction of a chimney. In the southwestern part, an opening was made in the ceiling over the basement and a staircase with stairs leading to the basement and the attic was built; secondary partitions were also introduced in the interior of the ground floor. In the south-western elevation, the outside doors to the basement were walled up, replacing them with a window, and bars were installed on all of the windows.

Over the course of the adaptations which began in 1971, the following changes were made. The Purification House was connected to the gardener's house with a single-storey, brick connector - without a basement and covered by bituminous roofing paper. An additional layer of brick was added to the walls of the Bet Tahara, the wooden floor structures were taken apart, replacing them with brick-infill floors (so-called "Klein floors") with slag infill, and secondary columns were placed in the center of the mourning hall, which supported the reinforced concrete ceiling partitioning the interior into two stories. The unique ceiling was also equipped with an access hole and window, which provided the interior formed under the pyramid with light. The boiler room was moved from the ground floor to the basement, which made it necessary to build a second, massive chimney in the southwestern corner. Because a garage was also located in the basement, an opening for a wide entrance gate was made in the southwestern wall. Changing the function of the basement made it necessary to lower the level of the ground next to the southwestern elevation of the building. 
The escarpment on which the building stands was cut into, creating a retaining wall, and an outhouse for a half bath was added [6].

Despite numerous modifications, the Olsztyn building was maintained in relatively good condition. The outside and load-bearing walls, structure of the roof and above all, the most valuable element - the pyramidal ceiling vault, did not undergo serious damage. Terrazzo floors and small fragments of the originally decorated plasters were retained inside.

In 2006, renovation works on the building were commenced, during which the columns and secondary ceiling in the mourning hall were removed, and restoration of the ceiling vault assumed, along with cleaning works on the building and its surroundings. The comprehensive revitalization of the Bet Tahara, however, did not start until 2009, when the undertaking received additional funding from the European Union.

\section{VALUE ESTABLISHING ANALYSIS}

The potential for revitalizing Bet Tahara was assessed as high due to its historic and artistic value [3], rather good technical condition, great location in the city center, clear legal status, possibility of changing the functional use without loss to the substance of the building and unpermitted changes, the community's engagement in the renovation and a clearly established goal - designating the building for cultural-educational purposes.

\section{SCOPE OF RENOVATION WORK}

The drying and perimeter insulation of the foundation walls, regulating the level of the ground and proper formation of the escarpment on the northwestern side of the building were considered to be the most urgent renovation works [2].

At the same time, some construction elements of the roof framework (damaged from biological degradation and flooding of the attic with rainwater resulting from the roof leaking prior to its renovation) and strengthening the roof framework by introducing an additional post wall. The roof slope was subjected to thermomodernization by adding a $20 \mathrm{~cm}$ layer of mineral wool, filling in the missing roof cover and installing new roof flashing.

Weight was taken off the existing brick infill (Klein) floors by replacing the 12 $\mathrm{cm}$ layer of slag with mineral wool [5]. The secondary layer of brick and secondary layers of paint were removed from the mourning hall, and plaster mosaics and polychromy recreated. The original window and door openings were restored, replacing the windows and doors as well as sanitary and electrical fittings, and installing a new mechanical ventilation system [5]. 
New stairs were also constructed: in the atrium leading to the attic and in the southwestern part leading to the storage area in the basement and to the attic [5]. In these areas, where stairs and a service elevator are located, the existing brick infill floors were replaced with reinforced concrete floors on steel beams, which were laid transversely (beams of the brick infill floors were oriented longitudinally) and placed on existing binding joists. The change in the direction of the beam behavior made it possible to take weight off the lintels over the gates in the exterior walls which had cracked due to being overloaded.

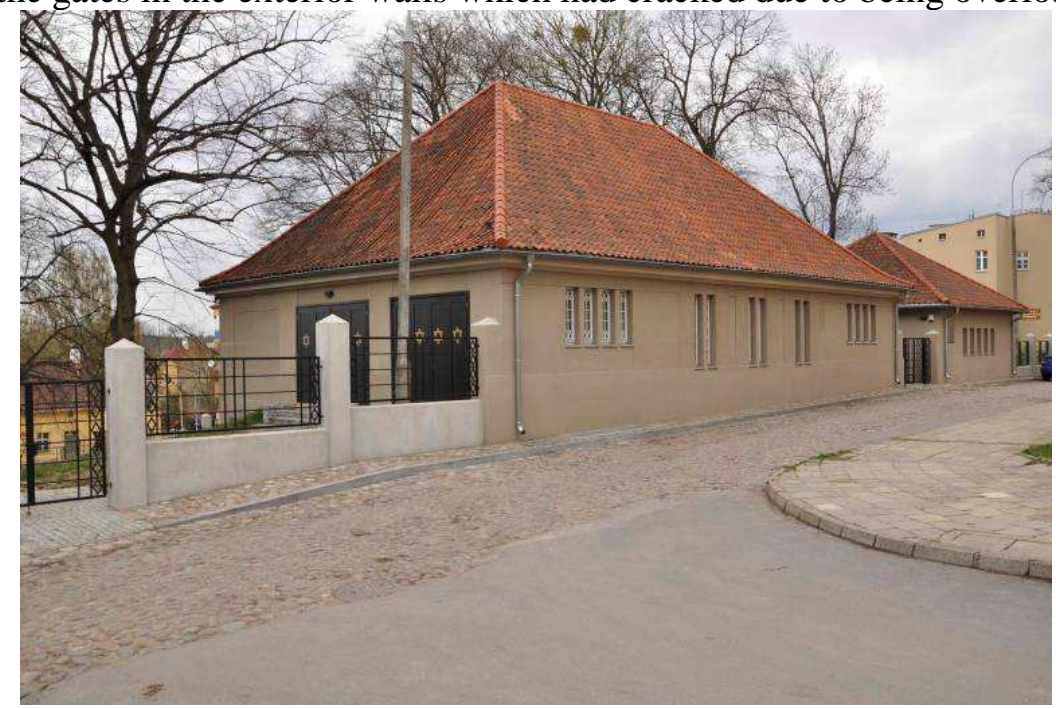

Fig. 7. Bet Tahara building complex following renovation [photograph byA. Skrzypińska, 2014]

The conservation works performed on the building made the original functions of the rooms and divisions of the elevation clearer (Fig. 7). Currently, conservation works are underway on historic matzevot, which were obtained during the renovation of another historical building - villa Casablanca (they had been used in the 60's of the XX century to reinforce the escarpment next to it).

\section{CONCLUSIONS}

The renovation and adaptation of the former Jewish Purification House to serve new functions is an example of the revalorization of a building with high potential for revitalization. As a result of the carried out undertaking, the city acquired a valuable utility building, which is confirmed by the cultural projects and numerous visits of residents as well as tourists interested in the creative output of Erich Mendelsohn. 


\section{REFERENCES}

1. Karta ewidencyjna zabytków $i$ architektury budownictwa domu przedpogrzebowego przy ul. Zyndrama $z$ Maszkowic $w$ Olsztynie. Archiwum MOSOZ w Olsztynie.

2. Martino J., Gibczyński M.: Badania konserwatorskie wnętrz $i$ na elewacjach dawnego domu przedpogrzebowego (Bet Tahara) potożonego przy ul Zyndrama z Maszkowic 2 w Olsztynie, Olsztyn 2010.

3. Martino J.: Dom przedpogrzebowy projektu Ericha Mendelsohna. Problematyka konserwatorska, Renowacje i zabytki, 48, 4 (2013) 87-90.

4. Rzempołuch A.: Architektura $i$ urbanistyka Olsztyna 1353-1953, Wydawnictwo Urzędu Miasta Olsztyn, Olsztyn 2004.

5. Zyskowska M., Wojciechowska-Grygo A.: Projekt przebudowy i adaptacji dawnego domu przedpogrzebowego Bet Tahara na Centrum Dialogu Międzykulturowego „Dom Mendelsohna” wraz z projektem uczytelnienia zabytkowego cmentarza przy ul. Zyndrama z Myszkowic w Olsztynie, Olsztyn 2010.

\section{RENOWACJA I ADAPTACJA ZABYTKOWEGO OLSZTYŃSKIEGO DOMU OCZYSZCZEŃ BET TAHARA NA BUDYNEK UŻYTECZNOŚCI PUBLICZNEJ}

\section{Streszczenie}

W 2013 roku w Olsztynie zakończono rewitalizację zabytkowego żydowskiego Domu Oczyszczeń Bet Tahara, który został wybudowany w 1913 r. na podstawie projektu światowej sławy architekta Ericha Mendelsohna. Analiza wartościująca wykazała istotną wartość historyczną i artystyczną obiektu, jego dość dobry stan techniczny, świetną lokalizację w centrum miasta, uregulowany stan prawny, możliwość zrealizowania nowej funkcji użytkowej bez strat dla substancji budynku i niedopuszczalnych przekształceń oraz precyzyjnie określony cel rewitalizacji - przeznaczenie obiektu na cele edukacyjnokulturalne.

W artykule opisano interesującą konstrukcję budynku (którego najcenniejszym elementem jest samonośne ostrosłupowe sklepienie nad salą pożegnań), jego stan techniczny przed renowacją oraz zakres prac związanych $\mathrm{z}$ adaptacją na budynek użyteczności publicznej-Centrum Dialogu Międzykulturowego DOM MENDELSOHNA. Renowacja kompleksu budynków Bet Tahara nie byłaby możliwa bez zaanagażowania społecznego, to znaczy wolontariuszy Stowarzyszenia Wspólnota Kulturowa „Borussia” współpracujących z Fundacją Ochrony Dziedzictwa Żydowskiego. 
Słowa kluczowe: renowacja zabytku, adaptacja, żydowski Dom Oczyszczeń, budynek użyteczności publicznej

Editor received the manuscript: 15.12 .2014 